\title{
New isotopic evidence of lead contamination in wheat grain from atmospheric fallout
}

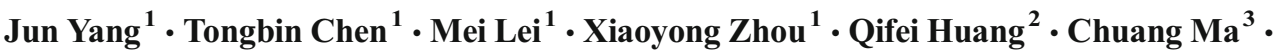 \\ Runyao Gu ${ }^{1}$ - Guanghui Guo ${ }^{1}$
}

Received: 17 January 2015 / Accepted: 23 April 2015 /Published online: 17 May 2015

(C) Springer-Verlag Berlin Heidelberg 2015

\begin{abstract}
Crops could accumulate trace metals by soil-root transfer and foliar uptake from atmospheric fallout, and an accurate assessment of pollution sources is a prerequisite for preventing heavy metal pollution in agricultural products. In this study, we examined $\mathrm{Pb}$ isotope rates to trace the sources of $\mathrm{Pb}$ in wheat grain grown in suburbs. Results showed that, even in zones with scarcely any air pollution spots, atmospheric fallout was still a considerable source of $\mathrm{Pb}$ accumulation in wheat. The concentration of $\mathrm{Pb}$ in wheat grain has poor correlation with that in farm soil. The $\mathrm{Pb}$ concentration in wheat grains with dust in bran coat was significantly higher than that in wheat grains, which indicates that $\mathrm{Pb}$ may accumulate by foliar uptake. The $\mathrm{Pb}$ isotope rate has obvious differences between the soil and atmospheric fallout, and scatter ratio is significantly closer between the wheat grain and atmospheric fallout. Atmospheric fallout is a more significant source of $\mathrm{Pb}$ concentration in wheat grains than in soil. As far as we know, this is the first study on the main sources of lead in grain crop (wheat) samples with isotope. This study aims to improve our
\end{abstract}

Responsible editor: Gerhard Lammel

Mei Lei

Leim@igsnrr.ac.cn

1 Center for Environmental Remediation, Institute of Geographic Sciences and Natural Resources Research, Chinese Academy of Sciences, 11A Datun Road, Beijing 100101, China

2 State Key Laboratory of Environmental Criteria and Risk Assessment, Chinese Research Academy of Environmental Sciences, Beijing 100012, China

3 Collaborative Innovation Center of Environmental Pollution Control and Ecological Restoration, Zhengzhou University of Light Industry, Henan Province Zhengzhou 450001, China understanding of the translocation of foliar-absorbed metals to nonexposed parts of plants.

Keywords $\mathrm{Pb}$ isotopic $\cdot \mathrm{Pb}$ contamination $\cdot$ Wheat grain . Atmospheric $\cdot$ Fallout $\cdot$ Soil

\section{Introduction}

Lead $(\mathrm{Pb})$ contamination and its health effects are widespread around the world (Duzgoren-Aydin et al. 2004; Rankin et al. 2005). The unhealthy effects of $\mathrm{Pb}$ include neurological impairment and deficits in the function of the central nervous system (Huang et al. 2011; Ortega et al. 2013; SzkupJablonska et al. 2012). The $\mathrm{Pb}$ accumulation in crops represents an important route of toxins into human food chains (Henson and Reardon 2005; Luo et al. 2012; McHugh and Avena-Bustillos 2011). Wheat (Triticum aestivum L.) is an important crop worldwide as a basic food commodity (Food and Agriculture Organization 2013). Various studies have revealed the link between the different degrees of $\mathrm{Pb}$ pollution in wheat grains and the threat they pose to human beings (Bermudez et al. 2011, 2012; Boussen et al. 2013; Douay et al. 2008; Nan et al. 2002). Preventing Pb pollution in wheat grains is necessary for food safety, which requires accurate verification of pollution sources.

The existing methods of heavy metal source tracing in plants include field test, mathematical analysis, and isotopic tracing. Douay et al. (2008) compared the $\mathrm{Pb}$ contents in wheat grains before and after closure of a local $\mathrm{Pb}$ and $\mathrm{Zn}$ smelter and found that, after the shutdown, the $\mathrm{Pb}$ contents in wheat grains and straw decreased by 82 and $91 \%$, respectively. These findings indicated that the atmospheric fallout from the smelter was responsible for the $\mathrm{Pb}$ pollution in wheat. 
Harrison and Chirgawi (1989) used growth cabinets with filtered air to demonstrate the effect of airborne metals on several plant species; the atmospheric contribution of $\mathrm{Pb}$ to the contamination of spinach was up to $85 \%$. Bermudez et al. (2012) set up a linear regression model based on the $\mathrm{Pb}$ contents in atmospheric fallout, root soil, and wheat grains to assess the contributions of various sources. However, mathematical analysis can hardly be conducted on the limited data acquired from field tests, and setting a control group presents a problem.

Fractionation because of microbial, chemical, and physical processes has no influence on the isotopic ratio of $\mathrm{Pb}$ in the environment; thus, $\mathrm{Pb}$ isotope has been employed to track heavy metal assimilation paths in plants. Hu et al. (2011) used ${ }^{210} \mathrm{~Pb}$ to estimate quantitatively the amount of lead for Aster subulatus, and the results showed that the approximate contribution of airborne $\mathrm{Pb}$ in plant leaves was $72.2 \%$. Dollard (1986) used ${ }^{210} \mathrm{~Pb}$ to examine the foliar uptake and redistribution of lead in several plant species and found that $\mathrm{Pb}$ foliar absorption accounts for approximately $35 \%$ of the internal lead burden of radish root tissues, but only for $3 \%$ of the $\mathrm{Pb}$ in carrots. ${ }^{206} \mathrm{~Pb} /{ }^{207} \mathrm{~Pb}$ ratios indicated that the $\mathrm{Pb}$ in the needles of pine trees in Sweden was dominated by direct $\mathrm{Pb}$ accumulation from the atmosphere (Uzu et al. 2010). Corn plants around an industrial air pollutant (smelter) assimilated the atmospheric fallout through their leaves and transferred them to the grains, as revealed by the isotopic tracing test conducted by Bi et al. (2009). However, most of the available data focus only on the effect of atmospheric dust on plants, and research on the effects on cereal grain is limited.

The objective of the present study is to trace the contributions of the suburban atmospheric fallout to the lead content in grain crops (wheat) with $\mathrm{Pb}$ isotope. The results are intended to improve our understanding of the translocation of foliarabsorbed metals to nonexposed parts of plants. As far as we know, this is the first study on the main sources of lead on grain crop (wheat) samples with isotopes collected from a suburban area.

\section{Materials and methods}

\section{Study area}

The experiment was conducted in the east-south suburb of Beijing in North China Plain, the main wheat-producing area in China. The industrial-structural adjustment resulted in the relocation of the smelting industry to the surrounding cities (e.g., Shougang Group moved to Tangshan, Hebei province). Thus, the study area is clear of air pollution. The dominant crops in the study area are corn and wheat. The annual precipitation is $620 \mathrm{~mm}$. The main soil types are fluvo-aquic (calcaric cambisol) and cinnamon (anthrosol). The soil $\mathrm{pH}$ of the study area is 7.8-8.6.

\section{Sampling}

Three sampling points were distributed in the study area as shown in Fig. 1. Samplers were installed on a telegraph pole in the southeast suburb of Beijing, over $5 \mathrm{~m}$ above ground, to avoid disturbance from surrounding buildings and secondary blowing dust. Fifty milliliters of hexanediol was added to the samplers in advance to keep the sampler moist while inhibiting microbes and algae. After the leaves and insects were removed, distilled water was added to wash out the retained dust. The mixture was kept in a refrigerator before analysis.

Atmospheric fallout was sampled monthly from February to July in 2008. A total of 14 samples were collected. A total of 21 wheat grain samples and corresponding root-soil samples were also collected. Sampling spots were distributed as shown in Fig. 1.

\section{Chemical analyses}

Natural dried soil samples were ground to 100 mesh, and approximately $300 \mathrm{mg}$ of sample was digested with $6 \mathrm{ml}$ of $\mathrm{HCl}(30 \%, v / v), 2 \mathrm{ml}$ of $\mathrm{HNO}_{3}(65 \%, v / v)$, and $2 \mathrm{ml}$ of $\mathrm{HF}$ $(40 \%, v / v)$ in a microwave digestion system (MARS 5, CEM) for $30 \mathrm{~min}$ (Bi et al. 2009). The digested solution was diluted with $25 \mathrm{ml}$ of Milli-Q water. Atmospheric fallout samples $(200 \mathrm{mg})$ were digested with $6 \mathrm{ml}$ of $\mathrm{HCl}(30 \%, v / v), 2 \mathrm{ml}$ of $\mathrm{HNO}_{3}(65 \%, v / v)$, and $2 \mathrm{ml}$ of $\mathrm{HF}(40 \%, v / v)$ in a microwave digestion system (MARS 5, CEM) for $30 \mathrm{~min}$ after the digested mixture was dissolved to $25 \mathrm{ml}$ (Bi et al. 2009). The $\mathrm{Pb}$ concentrations of the solutions were determined via flame atomic absorption spectrometry (AAS 5100, Perkin-Elmer Inc.).

To compare the difference in $\mathrm{Pb}$ concentrations between wheat grains and wheat grains with dust in bran coat, we divided wheat seed samples into two groups; one group was washed with deionized water and dried to a constant weight, and the other group was dried to a constant weight without washing. The dried wheat seeds were then ground, and the samples $(500 \mathrm{mg})$ were digested with $6 \mathrm{ml}$ of $\mathrm{HNO}_{3}(65 \%$, $v / v)$ and $2 \mathrm{ml}$ of $\mathrm{H}_{2} \mathrm{O}_{2}(30 \%, v / v)$ in a microwave digestion system for $30 \mathrm{~min}$ (Bi et al. 2009). The digested solution was diluted with $25 \mathrm{ml}$ of Milli-Q water. The $\mathrm{Pb}$ contents of the solutions were determined with graphite furnace atomic absorption spectrometry (AAS 5100, Perkin-Elmer Inc.).

Nationally certified reference materials of soil (GSS-1, GSS-2) and plant (GSV-1, GSV-3) were followed for quality control. The results showed that the recovery rate of heavy metals in the soil and plant samples were within the allowable/ acceptable range of the nationally certified reference 
Fig. 1 Sketch map showing the sampling sites in the southeastern suburbs of Beijing, China

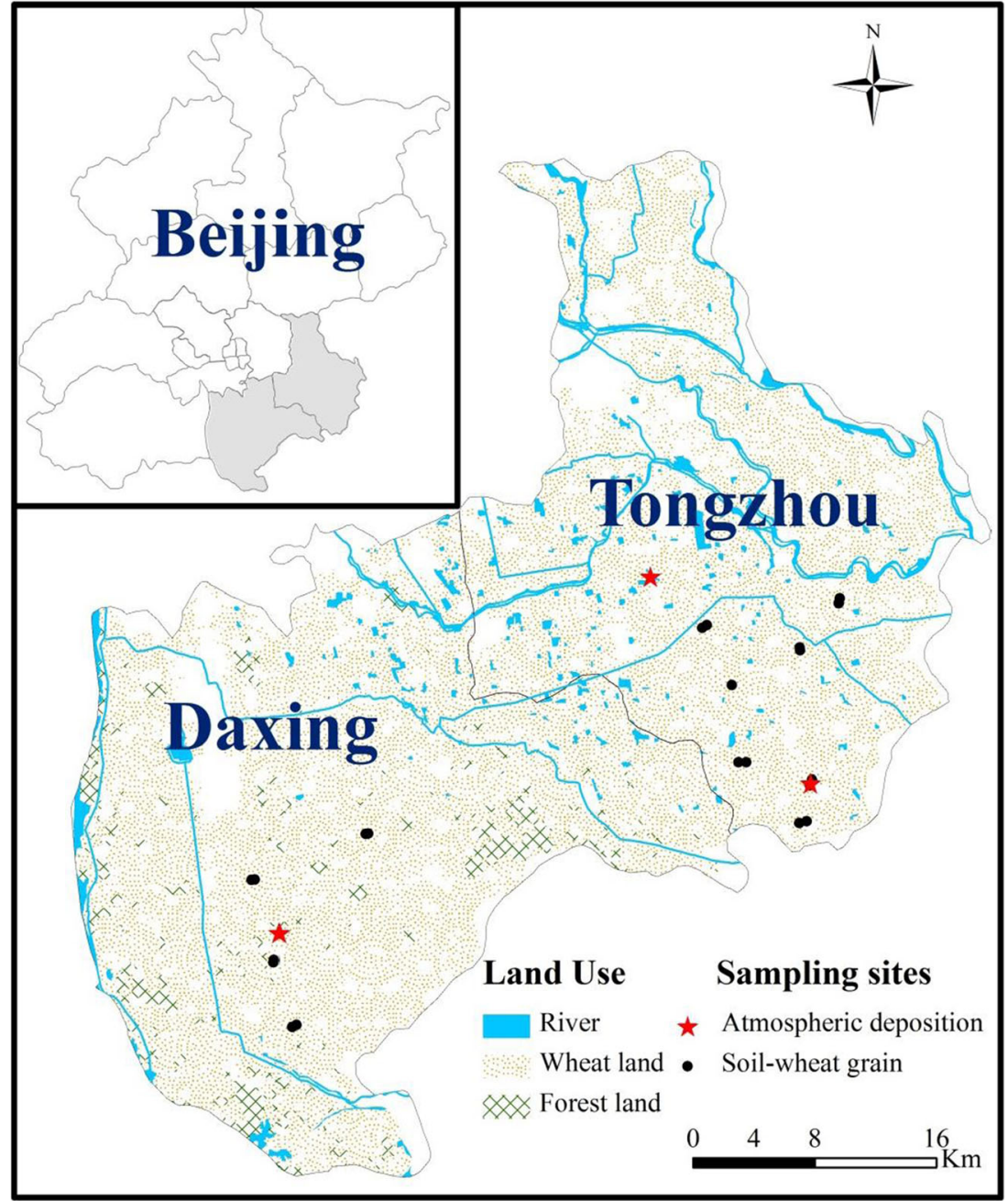

materials. The recovery rate of $\mathrm{Pb}$ in the standard plant samples was $90.6 \pm 5.1 \%(84.5-115 \%$ as required by the national standard), and the recovery rate of $\mathrm{Pb}$ in the standard soil samples was $95.6 \pm 4.1 \%(85.0-115 \%$ as required by the national standard).

\section{Isotope analysis}

The $\mathrm{Pb}$ isotopic composition was analyzed for atmospheric fallout, soil, and wheat grain samples by ICP-MS (PerkinElmer Elan $6100 \mathrm{DRC}^{\text {plus }}$ ) at the Beijing Research Institute of Uranium Geology. The details of the procedure were based on the determinations for isotopes of lead, strontium, and neodymium in rock samples (GB/T 17,672-1999). Standard material was used for the isotopic ratio of $\mathrm{Pb}$ (SRM981, common lead isotopic material, National Institute of Standards and Technology, USA). The samples were analyzed four times. The instruments were calibrated with a standard material for $\mathrm{Pb}$ (SRM981) for every three samples (Bi et al. 2009; Hu et al. 2011). The analysis was repeated when the difference between the measured and certified values of the standard reference material exceeded $0.5 \%$. The average $\mathrm{Pb}$ ratios of ${ }^{206} \mathrm{~Pb} /{ }^{207} \mathrm{~Pb}$ and ${ }^{208} \mathrm{~Pb} /{ }^{207} \mathrm{~Pb}(1.0909 \pm 0.0011$ and $2.3625 \pm 0.0021)$ were in good agreement with the standard reference values (1.0933 and 2.3704, respectively).

\section{Result and discussion}

\section{$\mathrm{Pb}$ concentration in soil and atmospheric fallout}

No significant $\mathrm{Pb}$ pollution was found in the study area. The $\mathrm{Pb}$ content in the soil in the study area $\left(12.66 \pm 1.13 \mathrm{mg} \mathrm{kg}^{-1}\right)$ was lower than the background content in the urban Beijing district (content $24.6 \pm 5.8 \mathrm{mg} \mathrm{kg}^{-1}$; range $11.5-38.2 \mathrm{mg} \mathrm{kg}^{-1}$ ) and was close to the rate reported by Zheng et al. (2008).

The $\mathrm{Pb}$ content in the atmospheric fallout was $120.3 \pm$ $6.08 \mathrm{mg} \mathrm{kg}^{-1}\left(77.1-194.5 \mathrm{mg} \mathrm{kg}^{-1}\right)$ in the study area. The $\mathrm{Pb}$ concentrations in the atmospheric fallout sampled from three sites were $117.2 \pm 43.0 \mathrm{mg} \mathrm{kg}^{-1}, 116.4 \pm 8.16 \mathrm{mg} \mathrm{kg}^{-1}$, and $127.3 \pm 43.0 \mathrm{mg} \mathrm{kg}^{-1}$ (Fig. 2), close to the $\mathrm{Pb}$ content in the total suspended particulates (TSP) emitted by thermo- 


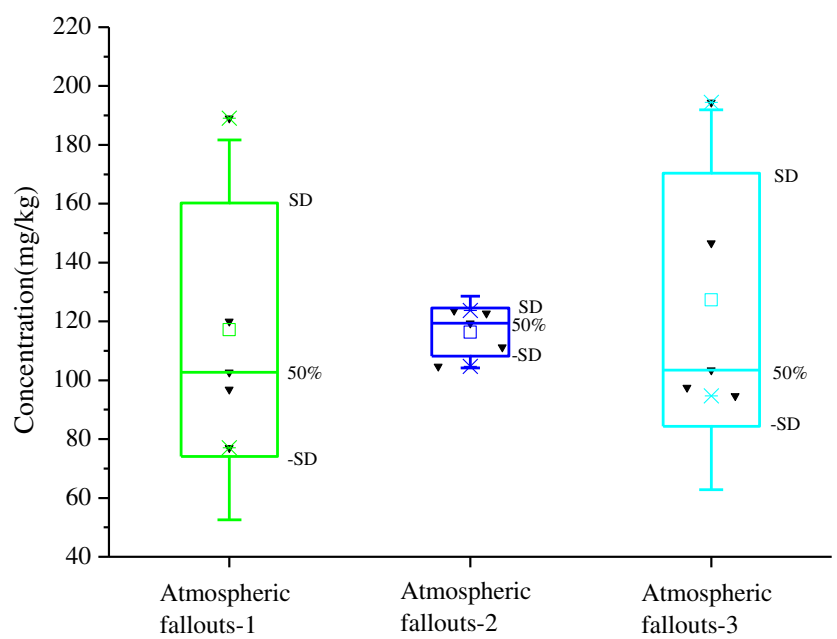

Fig. $2 \mathrm{~Pb}$ concentration of atmospheric fallout in the southeastern suburbs of Beijing, China

electric plants in Beijing as reported by Widory et al. (2010), higher than the $\mathrm{Pb}$ content in the TSP emitted by cement

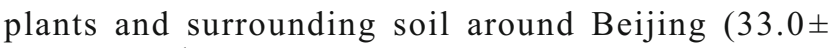
$8.00 \mathrm{mg} \mathrm{kg}^{-1}$ ) (Widory et al. 2010), and significantly lower than the $\mathrm{Pb}$ content in the TSP emitted by smelters in Hebei province (16,100-44,400 $\mathrm{mg} \mathrm{kg}^{-1}$ ) (Liu et al. 2011).

The ratio range for ${ }^{206} \mathrm{~Pb} /{ }^{207} \mathrm{~Pb}$ in the atmospheric fallout in this study was $1.166-1.179$ (Fig. 3), which was evidently higher than the content in petrol (1.06-1.09) and the TSP near lead-refining plants (1.137-1.156), partially overlapping with the industrial coal dust in Beijing (1.157-1.176) and the soil of Inner Mongolia (1.173-1.181).

Although no perceptible industrial air pollution point is around the study area, the diffusion of atmospheric fallout from a long distance leads to a mixture of $\mathrm{Pb}$ from multiple sources in this area (Gouin et al. 2004; Inoue et al. 2014). Despite the strong decrease in industrial and vehicle lead emissions at a global scale in recent decades (Glorennec

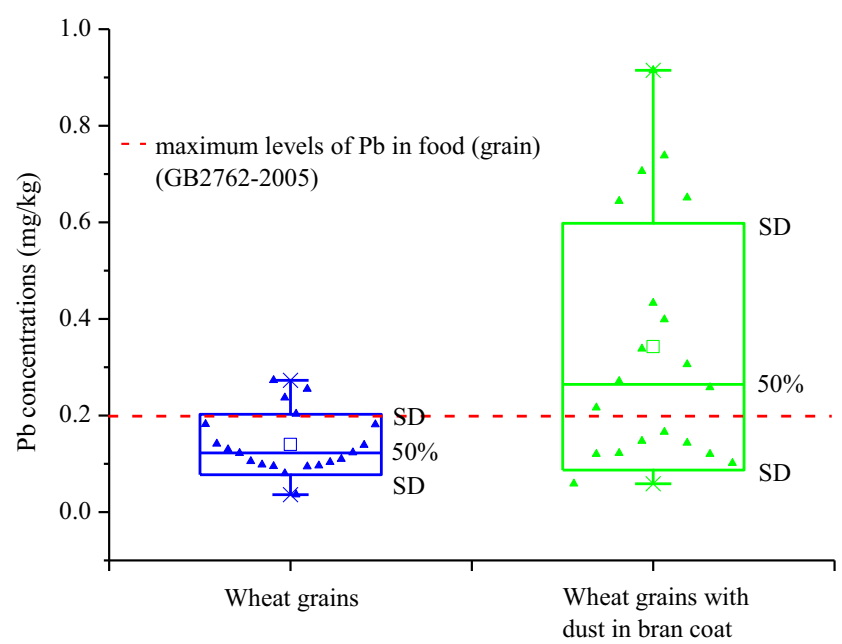

Fig. 4 Comparison of $\mathrm{Pb}$ concentration in wheat grains and wheat grains with dust in bran coat

et al. 2007), lead-enriched particles are still emitted to the environment, especially by coal combustion (Diaz-Somoano et al. 2009). Coal burning and biowaste burning account for $27 \%$ of the $\mathrm{PM}_{2.5}$ (aerosol particles with aerodynamic diameter less than $2.5 \mu \mathrm{m}$ ) pollution in Beijing in 2009. Apart from coal burning, the long distance transfer of dust from Inner Mongolia also contributes to the $\mathrm{Pb}$ in the atmospheric fallout in Beijing. It accounts for $23 \%$ of the $\mathrm{PM}_{2.5}$ pollution in Beijing during the Spring Festival.

\section{$\mathrm{Pb}$ concentration in wheat grain}

The $\mathrm{Pb}$ concentration in wheat grains ranged from 0.036 to $0.273 \mathrm{mg} \mathrm{kg}^{-1}$, and the average value was $0.140 \pm$ $0.062 \mathrm{mg} \mathrm{kg}^{-1}$ (Fig. 4). Four grain samples (accounting for $20 \%$ of the total samples) in this study had higher concentrations of $\mathrm{Pb}$ than the national guidance limit for various types of food in China $\left(0.2 \mathrm{mg} \mathrm{Pb} \mathrm{kg}{ }^{-1}\right)$ (National Health and
Fig. $3{ }^{206} \mathrm{~Pb} /{ }^{207} \mathrm{~Pb}$ ratio in different mediums

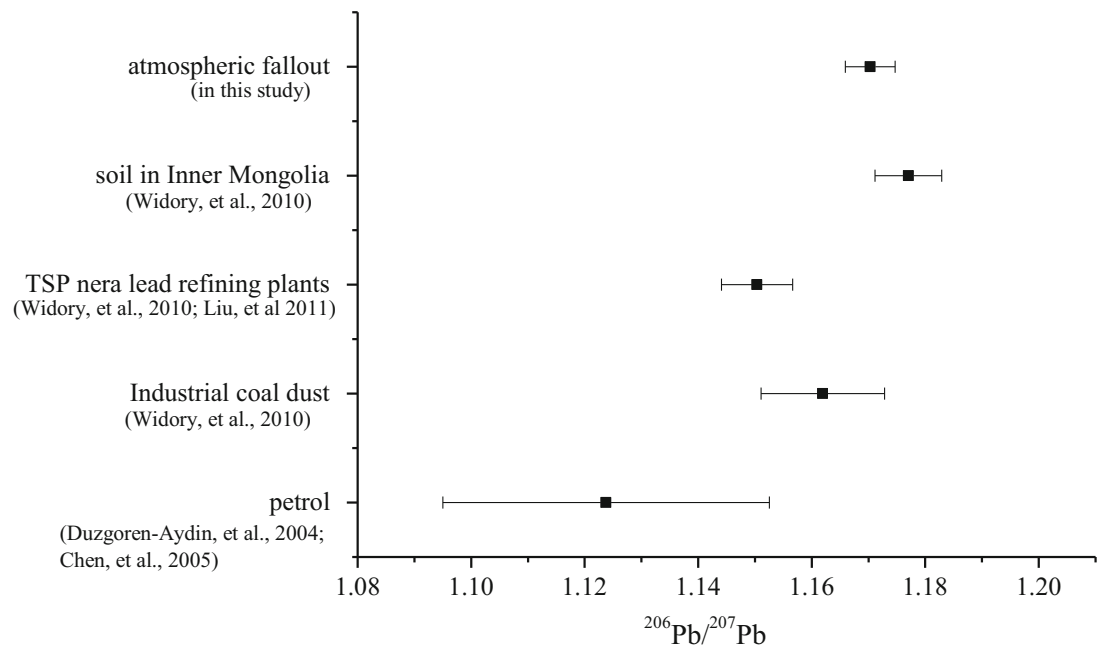




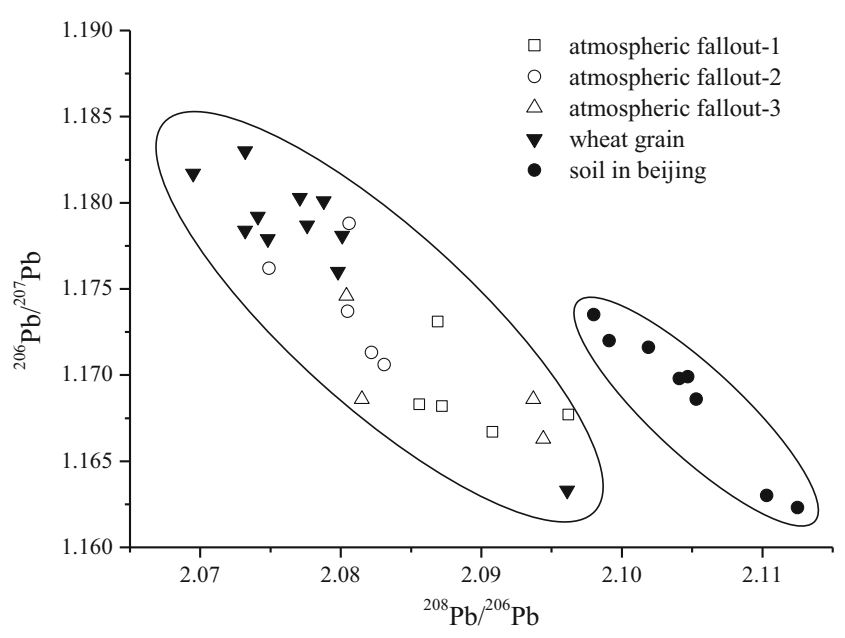

Fig. $5{ }^{206} \mathrm{~Pb} /{ }^{207} \mathrm{~Pb}-{ }^{208} \mathrm{~Pb} /{ }^{206} \mathrm{~Pb}$ ratio scatter diagram of different mediums

Family Planning Commission of China 2012). Compared with the findings of previous studies, the wheat grains in the study area were slightly polluted, with a $\mathrm{Pb}$ content of $0.140 \pm$ $0.062 \mathrm{mg} \mathrm{kg}^{-1}$, which was lower than the level (1.31 and $0.65 \mathrm{mg} \mathrm{kg}^{-1}$ ) in the zones polluted by smelters (Douay et al. 2008; Pruvot et al. 2006) and that in Baiyin, Gansu province, China, where plants were irrigated by polluted water ( $0.48 \mathrm{mg} \mathrm{kg}^{-1}$ ) (Nan et al. 2002). The pollution level in the study area was also slightly higher than the $0.088 \mathrm{mg} \mathrm{kg}^{-1}$ rate in the agricultural zone in Córdoba, Argentina (Bermudez et al. 2011).

The $\mathrm{Pb}$ concentration in wheat grains with dust in bran coat ranged from 0.059 to $0.915 \mathrm{mg} \mathrm{kg}^{-1}$, and the average value was $0.343 \pm 0.255 \mathrm{mg} \mathrm{kg}^{-1}$. The $\mathrm{Pb}$ concentration in wheat grains with dust in bran coat was 2.04 times that of the concentration in wheat grains. The difference in the test of statistical significance indicated that the $\mathrm{Pb}$ concentration in wheat grains with dust in bran coat was significantly higher than that in wheat grains $(p=0.008<0.05)$.

\section{Contribution of soil lead to wheat-seed lead content}

In the present study, correlation analyses between the $\mathrm{Pb}$ concentrations in soils and in the wheat grains showed that soil $\mathrm{Pb}$ concentrations were not significantly correlated to the $\mathrm{Pb}$ concentrations in the wheat grains $(p=0.618>0.05)$. This result indicated that the $\mathrm{Pb}$ content in soil was not a determinant of the $\mathrm{Pb}$ content in wheat grains. According to Douay et al. (2008), the influence of soil $\mathrm{Pb}$ on wheat grain $\mathrm{Pb}$ content was significantly less than that of atmospheric fallout, even with a soil $\mathrm{Pb}$ concentration as high as $290 \mathrm{mg} \mathrm{kg}^{-1}$. Another study (Bi et al. 2009) showed that with a soil $\mathrm{Pb}$ concentration of $2300 \mathrm{mg} \mathrm{kg}^{-1}, \mathrm{~Pb}$ in corn mainly occurred in roots and scarcely in corn grains.

Accumulating $\mathrm{Pb}$ from soil is difficult for wheat grains because of the low bioavailability of $\mathrm{Pb}$ in the soil and the combination form of $\mathrm{Pb}$ in the roots. The contents of DTPAextractable $\mathrm{Pb}$ of soils in the study area accounted for $10.7 \%$ of the total amount of soil $\mathrm{Pb}$ and were significantly less than the contents of the DTPA-extractable $\mathrm{Cu}$ and $\mathrm{Cd}$ (Yang et al. 2005). A lower Pb bioavailability would inhibit the assimilation by plants. In the aspect of binding characteristics, $\mathrm{Pb}$ in the soil is nearly always tightly bound to organic or colloidal material or in a precipitated form, all of which serve to reduce the uptake of $\mathrm{Pb}$ by the plant roots. At the root surface, $\mathrm{Pb}$ binds to carboxyl groups of mucilage uronic acids. Mucilage binding restricts metal uptake into the root and establishes an

Table 1 Isotope ratios and elemental content of different mediums

\begin{tabular}{|c|c|c|c|c|c|c|c|c|}
\hline \multicolumn{3}{|c|}{ Atmospheric fallout } & \multicolumn{3}{|c|}{ Soil in Beijing } & \multicolumn{3}{|l|}{ Wheat grain } \\
\hline $\mathrm{Pb}(\mathrm{mg} / \mathrm{kg})$ & ${ }^{208} \mathrm{~Pb} /{ }^{206} \mathrm{~Pb}$ & ${ }^{206} \mathrm{~Pb} /{ }^{207} \mathrm{~Pb}$ & $\mathrm{~Pb}(\mathrm{mg} / \mathrm{kg})$ & ${ }^{208} \mathrm{~Pb} /{ }^{206} \mathrm{~Pb}$ & ${ }^{206} \mathrm{~Pb} /{ }^{207} \mathrm{~Pb}$ & $\mathrm{~Pb}(\mathrm{mg} / \mathrm{kg})$ & ${ }^{208} \mathrm{~Pb} /{ }^{206} \mathrm{~Pb}$ & ${ }^{206} \mathrm{~Pb} /{ }^{207} \mathrm{~Pb}$ \\
\hline 119.4 & 2.0806 & 1.1788 & 13.3 & 2.1019 & 1.1716 & 0.110 & 2.0798 & 1.176 \\
\hline 104.7 & 2.0749 & 1.1762 & 12.6 & 2.1047 & 1.1699 & 0.182 & 2.0748 & 1.1779 \\
\hline 122.8 & 2.0822 & 1.1713 & 10.6 & 2.0980 & 1.1735 & 0.139 & 2.0695 & 1.1817 \\
\hline 111.3 & 2.0805 & 1.1737 & 12.6 & 2.0991 & 1.1720 & 0.273 & 2.0732 & 1.1830 \\
\hline 123.7 & 2.0831 & 1.1706 & 11.9 & 2.1125 & 1.1623 & 0.103 & 2.0801 & 1.1781 \\
\hline 77.1 & 2.0856 & 1.1683 & 13.8 & 2.1053 & 1.1686 & 0.122 & 2.0788 & 1.1801 \\
\hline 102.7 & 2.0908 & 1.1667 & 12.1 & 2.1041 & 1.1698 & 0.13 & 2.0776 & 1.1787 \\
\hline 189.1 & 2.0869 & 1.1731 & 12.2 & 2.1103 & 1.1630 & 0.123 & 2.0771 & 1.1803 \\
\hline 96.9 & 2.0872 & 1.1682 & & & & 0.141 & 2.0741 & 1.1792 \\
\hline 120.0 & 2.0962 & 1.1677 & & & & 0.095 & 2.0732 & 1.1784 \\
\hline 146.6 & 2.0804 & 1.1746 & & & & 0.203 & 2.0961 & 1.1633 \\
\hline 194.5 & 2.0815 & 1.1686 & & & & & & \\
\hline 94.7 & 2.0937 & 1.1686 & & & & & & \\
\hline 97.5 & 2.0944 & 1.1663 & & & & & & \\
\hline
\end{tabular}


important barrier that protects the root system (Sharma and Dubey 2005). In the transfer paths in plants, $\mathrm{Pb}$ retention in the roots is based on the binding of $\mathrm{Pb}$ to ion exchangeable sites on the cell wall and on extracellular precipitation mainly in the form of $\mathrm{Pb}$-carbonated deposits in the cell wall, which restrict $\mathrm{Pb}$ transportation from the roots to the aboveground parts of plants (Krzeslowska 2011; Sharma and Dubey 2005). Therefore, the $\mathrm{Pb}$ concentrations transported from soil in the wheat grain are low and mainly accumulated in the roots, indicating that atmospheric fallout may be responsible for the presence of $\mathrm{Pb}$ in wheat grains.

\section{Contribution of atmospheric fallout to lead content in wheat seed}

The scatter plot in Fig. 5 shows that the ranges of $\mathrm{Pb}$ isotope ratios in wheat grain overlapped partially with those in the atmospheric fallout and were far from those in the soils. The wheat grains and atmospheric fallout were characterized by relatively high ${ }^{206} \mathrm{~Pb} /{ }^{207} \mathrm{~Pb}(1.163-1.190,1.166-1.179)$ and low ${ }^{208} \mathrm{~Pb} /{ }^{206} \mathrm{~Pb}(2.059-2.096,2.075-2.096)$. By contrast, soils exhibited a rather low ${ }^{206} \mathrm{~Pb} /{ }^{207} \mathrm{~Pb}(1.162-1.172)$ and high ${ }^{208} \mathrm{~Pb} /{ }^{206} \mathrm{~Pb}$ (2.098-2.113) (Table 1). A significant difference was observed between the $\mathrm{Pb}$ isotope compositions in the atmospheric fallout and in the soil.

As a result of different inputs, pathways may contain $\mathrm{Pb}$ with characteristic ratios. Tracing various $\mathrm{Pb}$ sources in a plant based on $\mathrm{Pb}$ isotope composition analyses is possible (Gwiazda and Smith 2000; Haack et al. 2004; Monna et al. 1997; Siu et al. 2005). In our study, the Pb content in the wheat grains was mainly derived from atmospheric fallout as indicated by similar isotope ratios. This finding is consistent with reported results that plant leaves can uptake $\mathrm{Pb}$ directly from atmospheric fallout (Bi et al. 2009; Dollard 1986; Hu et al. 2011; Uzu et al. 2010).

Lead may penetrate the leaf by two pathways. First, the lead-containing nanoparticles observed in the stomata may penetrate the apoplasm as solid compounds. Second, the lead resulting from the dissolution of source particles may diffuse through the aqueous pores of the cuticle and the stomata, following the hydrophilic pathway and inducing the formation of necroses enriched with lead (Uzu et al. 2010). According to Schreck et al. (2012), the original particles contained $\mathrm{PbS}$ and $\mathrm{PbS}$ transformed to lead secondary species $\left(\mathrm{PbCO}_{3}\right.$ and organic $\mathrm{Pb}$ ) on leaf surfaces, and some compounds were internalized in their primary form $\left(\mathrm{PbSO}_{4}\right)$ underneath an organic layer (Choël et al. 2006; Huang et al. 1994). However, for grains wrapped by coating, the accumulated $\mathrm{Pb}$ in wheat grain is possibly transported from the wheat bran bread via phloem. Some studies proved that foliar $\mathrm{Pb}$ could be translocated to actively growing regions. With the help of isotopic tracing, $\mathrm{Bi}$ et al. (2009) found that the $\mathrm{Pb}$ that settled on the leaves was assimilated by the leaf tissue and then transferred to the core grains. However, the manner by which $\mathrm{Pb}$ is transported to wheat grain should be explored in depth.

According to the results of our study, atmospheric fallout may be responsible for the $\mathrm{Pb}$ pollution in wheat grains even in farmlands away from industrial pollution sites. This study demonstrated a direct link between air pollution and the threat it poses to food safety. Air pollution is a serious problem in China partly because it threatens food safety. This study also represents a new exploration of the mechanism of $\mathrm{Pb}$ transfer between atmospheric fallout, grain plants (wheat), and soil system.

\section{Conclusion}

The $\mathrm{Pb}$ contents and their isotopic ratios in wheat grains, root soil, and atmospheric fallout collected during the wheatgrowing season were analyzed to identify the main source of $\mathrm{Pb}$ in wheat grains in the suburban study area. The results showed that the $\mathrm{Pb}$ content in root soil was weakly linked to the $\mathrm{Pb}$ content in wheat grains. Atmospheric fallout adheres to the theory that wheat grains may be responsible for the $\mathrm{Pb}$ assimilated by plants. The $\mathrm{Pb}$ isotope rates of the soil and atmospheric fallout had an obvious difference, and the scatter ratio was significantly closer between the wheat grain and atmospheric fallout. Atmospheric fallout was a more important source of $\mathrm{Pb}$ concentration in wheat grains than in soil. The assimilation of $\mathrm{Pb}$ from atmospheric fallout was the main transfer path of $\mathrm{Pb}$ in wheat grains. These findings provide new evidence to explore the $\mathrm{Pb}$ transfer mechanism in a multimedium system such as atmospheric fallout, grain plant (wheat), and soil. Such knowledge may be relevant from the perspective of risk assessment of atmospheric emissions in urban environments.

Acknowledgments This study was sponsored by the National Nature Science Foundation of China (41271478) and the 863 National Hi-tech Research \& Development Project (2012AA06A202, 2014AA06A513).

\section{References}

Bermudez GMA, Jasan R, Pla R, Pignata ML (2011) Heavy metal and trace element concentrations in wheat grains: assessment of potential non-carcinogenic health hazard through their consumption. J Hazard Mater 193:264-271

Bermudez GMA, Jasan R, Pla R, Pignata ML (2012) Heavy metals and trace elements in atmospheric fall-out: their relationship with topsoil and wheat element composition. J Hazard Mater 213:447-456

Bi X, Feng X, Yang Y, Li X, Shin GPY, Li F, Qiu G, Li G, Liu T, Fu Z (2009) Allocation and source attribution of lead and cadmium in maize (Zea mays L.) impacted by smelting emissions. Environ Pollut 157(3):834-839

Boussen S, Soubrand M, Bril H, Ouerfelli K, Abdeljaouad S (2013) Transfer of lead, zinc and cadmium from mine tailings to wheat 
(Triticum aestivum) in carbonated Mediterranean (Northern Tunisia) soils. Geoderma 192:227-236

Chen JM, Tan MG, Li YL, Zhang YM, Lu WW, Tong YP, Zhang GL, Li Y (2005) A lead isotope record of shanghai atmospheric lead emissions in total suspended particles during the period of phasing out of leaded gasoline. Atmos Environ 39:1245-1253

China (2012) Standard 2762-2012: National food safety standard maximum levels of contaminants in foods. National Health and Family Planning Commission of China

Choël M, Deboudt K, Flament P, Lecornet G, Perdrix E, Sobanska S (2006) Fast evolution of tropospheric $\mathrm{Pb}$ - and $\mathrm{Zn}$-rich particles in the vicinity of a lead smelter. Atmos Environ 40(24):4439-4449

Diaz-Somoano M, Kylander ME, Lopez-Anton MA, Suarez-Ruiz I, Martinez-Tarazona MR, Ferrat M, Kober B, Weiss DJ (2009) Stable lead isotope compositions in selected coals from around the world and implications for present day aerosol source tracing. Environ Sci Technol 43(4):1078-1085

Dollard GJ (1986) Glasshouse experiments on the uptake of foliar applied lead. Environ Pollut 40(2):109-119

Douay F, Roussel H, Pruvot C, Waterlot C (2008) Impact of a smelter closedown on metal contents of wheat cultivated in the neighbourhood. Environ Sci Pollut Res 15(2):162-169

Duzgoren-Aydin NS, Li XD, Wong SC (2004) Lead contamination and isotope signatures in the urban environment of Hong Kong. Environ Int 30:209-217

Food and Agriculture Organization (2013) FAO Statistical yearbooksworld food and agriculture. 132. http://issuu.com/faooftheun/docs/ syb2013issuu. Accessed Sept 2014

Glorennec P, Bemrah N, Tard A, Robin A, Le Bot B, Bard D (2007) Probabilistic modeling of young children's overall lead exposure in France: integrated approach for various exposure media. Environ Int 33(7):937-945

Gouin T, Mackay D, Jones KC, Harner T, Meijer SN (2004) Evidence for the "grasshopper" effect and fractionation during long-range atmospheric transport of organic contaminants. Environ Pollut 128(1-2): $139-148$

Gwiazda RH, Smith DR (2000) Lead isotopes as a supplementary tool in the routine evaluation of household lead hazards. Environ Health Perspect 108(11):1091-1097

Haack U, Kienholz B, Reimann C, Schneider J, Stumpfl EF (2004) Isotopic composition of lead in moss and soil of the European Arctic. Geochim Cosmochim Acta 68(12):2613-2622

Harrison RM, Chirgawi MB (1989) The assessment of air and soil as contributors of some trace metals to vegetable plants I. Use of a filtered air growth cabinet. Sci Total Environ 83(1-2):13-34

Henson S, Reardon T (2005) Private agri-food standards: Implications for food policy and the agri-food system. Food Policy 30(3):241-253

Hu X, Zhang Y, Luo J, Xie M, Wang T, Lian H (2011) Accumulation and quantitative estimates of airborne lead for a wild plant (Aster subulatus). Chemosphere 82(10):1351-1357

Huang JW, Grunes DL, Kochian LV (1994) Voltage-dependent $\mathrm{Ca}^{2+}$ influx into right-side-out plasma membrane vesicles isolated from wheat roots: characterization of a putative $\mathrm{Ca}^{2+}$ channel. Proc Natl Acad Sci U S A 91(8):3473-3477

Huang H, Bihaqi SW, Cui LX, Zawia NH (2011) In vitro Pb exposure disturbs the balance between A beta production and elimination: The role of A beta PP and neprilysin. Neurotoxicology 32(3):300-306

Inoue $\mathrm{J}$, Momose A, Okudaira T, Murakami-Kitase A, Yamazaki H, Yoshikawa S (2014) Chemical characteristics of Northeast Asian fly ash particles: implications for their long-range transportation. Atmos Environ 95:375-382
Krzeslowska M (2011) The cell wall in plant cell response to trace metals: polysaccharide remodeling and its role in defense strategy. Acta Physiol Plant 33(1):35-51

Liu XD, Zhu XK, Dong SP, Li YW, Widory D, Yang HX, Li B (2011) Lead isotopic measurements and source study for size-selective aerosol samples in Beijing. J Chin Mass Spectrom Soc 32(3):151163 (in Chinese)

Luo CL, Yang RX, Wang Y, Li J, Zhang G, Li XD (2012) Influence of agricultural practice on trace metals in soils and vegetation in the water conservation area along the East River (Dongjiang River), South China. Sci Total Environ 431:26-32

McHugh TH, Avena-Bustillos RJ (2011) Novel food processing innovations to improve food safety and health. Prog Nutr 13(3):146-154

Monna F, Lancelot J, Croudace IW, Cundy AB, Lewis JT (1997) Pb isotopic composition of airborne particulate material from France and the southern United Kingdom: Implications for $\mathrm{Pb}$ pollution sources in urban areas. Environ Sci Technol 31(8):2277-2286

Nan ZR, Zhao CY, Li JJ, Chen FH, Sun W (2002) Relations between soil properties and selected heavy metal concentrations in spring wheat (Triticum aestivum L.) grown in contaminated soils. Water Air Soil Pollut 133(1-4):205-213

Ortega F, Counter SA, Buchanan LH, Parra AMC, Collaguaso MA, Jacobs AB, Rifai N, Hoover PN (2013) Declining blood lead and zinc protoporphyrin levels in Ecuadorian Andean children. Clin Biochem 46(13-14):1233-1238

Pruvot C, Douay F, Herve F, Waterlot C (2006) Heavy metals in soil, crops and grass as a source of human exposure in the former mining areas. J Soil Sedim 6(4):215-220

Rankin CW, Nriagu JO, Aggarwal JK, Arowolo TA, Adebayo K, Flegal AR (2005) Lead contamination in cocoa and cocoa products: isotopic evidence of global contamination. Environ Health Perspect 113(10):1344-1348

Schreck E, Foucault Y, Sarret G, Sobanska S, Cecillon L, Castrec-Rouelle M, Uzu G, Dumat C (2012) Metal and metalloid foliar uptake by various plant species exposed to atmospheric industrial fallout: mechanisms involved for lead. Sci Total Environ 427:253-262

Sharma P, Dubey RS (2005) Lead toxicity in plants. Braz J Plant Physiol 17(1):35-52

Siu CL, Lee L, Li XD, Zhang G, Peng XZ, Zhang L (2005) Biomonitoring of trace metals in the atmosphere using moss (Hypnum plumaeforme) in the Nanling Mountains and the Pearl River Delta, Southern China. Atmos Environ 39(3):397-407

Szkup-Jablonska M, Karakiewicz B, Grochans E, Jurczak A, NowakStarz G, Rotter I, Prokopowicz A (2012) Effects of blood lead and cadmium levels on the functioning of children with behaviour disorders in the family environment. Ann Agr Env Med 19(2):241-246

Uzu G, Sobanska S, Sarret G, Munoz M, Dumat C (2010) Foliar lead uptake by lettuce exposed to atmospheric fallouts. Environ Sci Technol 44(3):1036-1042

Widory D, Liu XD, Dong SP (2010) Isotopes as tracers of sources of lead and strontium in aerosols (TSP \& PM2.5) in Beijing. Atmos Environ 44(30):3679-3687

Yang J, Chen TB, Zheng YM, Luo J, Liu HL, Wu WY, Chen Y (2005) Dynamic of heavy metals in wheat grains collected from the Liangfeng Irrigated Area, Beijing and a discussion of availability and human health risks. Acta Sci Circums 25(12):1661-1668 (in Chinese)

Zheng YM, Chen TB, He JZ (2008) Multivariate geostatistical analysis of heavy metals in topsoils from Beijing, China. J Soil Sedim 8(1):5158 